\title{
Antioxidative and Antihypertensive Activities of Selected Malaysian ulam (salad), Vegetables and Herbs
}

\author{
Norhayati Mustafa Khalid ${ }^{1} \&$ Abdul Salam Babji ${ }^{2}$ \\ ${ }^{1}$ Nutrition Unit, Cardiovascular, Diabetes and Nutrition Research Centre, Institute for Medical Research, Jalan \\ Pahang, 50588 Kuala Lumpur, Malaysia \\ ${ }^{2}$ School of Chemical Sciences and Food Technology, Faculty of Science and Technology, Universiti Kebangsaan \\ Malaysia, 43600 Bangi, Selangor, Malaysia \\ Correspondence: Norhayati Mustafa Khalid, Nutrition Unit, Cardiovascular, Diabetes and Nutrition Research \\ Centre, Institute for Medical Research, Jalan Pahang, 50588 Kuala Lumpur, Malaysia. E-mail: \\ norhayatimustafakhalid@gmail.com
}

Received: December 29, 2017 Accepted: January 17, $2018 \quad$ Online Published: March 31, 2018

doi:10.5539/jfr.v7n3p27

URL: https://doi.org/10.5539/jfr.v7n3p27

\begin{abstract}
This study was conducted to investigate antioxidative and antihypertensive activities of selected Malaysian ulam (salad), vegetables and herbs. The aqueous extract of selected ulam (salad), vegetables and herbs were analysed for total phenolic content (TPC), antioxidant activities (2,2-diphenyl-1-picrylhydrazyl (DPPH) radical scavenging assay, 2,2-azino-bis(3-ethylbenzthiazoline-6-sulfonic acid (ABTS) radical cation scavenging assay and ferric reducing antioxidant power assay (FRAP) and antihypertension activity (angiotensin converting enzyme (ACE) inhibitory activity assay). TPC analysis showed that Polygonum minus contains significantly ( $\mathrm{p}<0.05$ ) highest phenolic compound at $48.23 \pm 0.17 \mathrm{mg} \mathrm{GAE} / \mathrm{g}$ as compared to other plants. DPPH analysis showed that $P$. minus had significantly $(\mathrm{p}<0.05)$ highest percentage of radical scavenging activity at $79.09 \pm 0.10 \%$ as compared to other plants. ABTS analysis showed that Sauropus androgynus had significantly ( $<<0.05)$ highest percentage of radical cation scavenging activity at $95.10 \pm 0.26 \%$ as compared to other plants. FRAP analysis showed that $P$. minus had significantly $\left(\mathrm{p}<0.05\right.$ ) highest ferric reducing power at $63.61 \pm 0.73 \mathrm{mmol} \mathrm{Fe} \mathrm{e}^{2+} / \mathrm{g}$ as compared to other samples. Murraya koenigii had the highest percentage of ACE inhibitory activity $(91.20 \pm$ $4.15 \%)$. Correlation analysis showed positive and significant $(\mathrm{p}<0.01)$ correlation between TPC and FRAP $(\mathrm{r}=$ 0.956), TPC and ABTS $(r=0.635)$, TPC and DPPH $(r=0.630)$ and TPC and ACE inhibitors $(r=0.645)$. This shows that Malaysian tropical plants especially $P$. minus are potential source of natural antioxidant and antihypertensive agents.
\end{abstract}

Keywords: antihypertensive activities, antioxidative activities, herbs, Ulam, vegetables

\section{Introduction}

Prevalence of mortality from non-communicable diseases (NCDs) such as cancer is increasing and it is an alarming rate (WHO report, 2014). Reactive oxygen species (ROS) include free radicals such as superoxide anion radicals $\left(\mathrm{O}_{2}{ }^{-}\right)$, hydroxyl radical $\left(\mathrm{OH}^{-}\right)$and non-radical species such as hydrogen peroxide $\left(\mathrm{H}_{2} \mathrm{O}_{2}\right)$ and singlet oxygen $\left({ }^{1} \mathrm{O}_{2}\right)$. ROS promote oxidative damage to biomolecules such as lipids, nucleic acids, proteins and carbohydrates that leads to ageing, cancer and other diseases (Campanella, Martini, Rita, \& Tomassetti, 2006). The phenolic antioxidant in plant was reported to capture oxygen free radicals by donating a hydrogen atom or electron to the free radical (Antolovich, Prenzler, Kevin, \& Danielle, 2002).

Malaysia is a tropical country with diverse species of flora and fauna due to the hot climate, high humidity and rain throughout the year. This climate led to the growth of various types of plant species including ulam (salad), vegetables and herbs (Mohd Faez et al., 2014). Ulam (salad) is defined as fresh or raw green salad that can been eaten with fermented sauce, herbs or spices as side dishes by the Malay community while vegetable refers to a plant that is often eaten either by blanching, boiled or stir-fried (Rukayah, 2000; Reihani \& Azhar, 2012). In addition to ulam (salad) and vegetables, Malaysian foods are also rich with herbs such as turmeric, kesum and ginger (Huda-Faujan, Noriham, Norrakiah, \& Babji, 2007).

Ulam (salad) and herbs with distinct smell and taste that increases appetite were widely consumed among various 
ethnic groups in Malaysia (Nurul Izzah et al., 2012). In addition, epidemiological studies show that consumption of vegetables can prevent the occurrence of diseases caused by oxidative stress such as cancer, hypertension, heart disease, and diabetes (Halvorsen, Carlsen, Philips, Bohn, \& Holte, 2006). This is due to high antioxidant content in vegetables such as carotenoids, phenolic compounds, benzoic acid, flavonoids, proanthocyanin, stilbene, coumarins, lignans and lignin (Lindsay \& Astley, 2002; Zheng \& Wang, 2001). Phenolic compounds from plants are beneficial as an effective angiotensin I-converting enzyme (ACE) inhibitors that lowers the blood pressure (Nadin et al., 2013).

Several studies had been conducted to evaluate antioxidant activity of ulam (salad), vegetables and herbs (Faridah, Nordin, Israf, Khozirah, \& Umi Kalsom, 2006; Huda-Faujan et al., 2007; Sivanesan \& Hazeena, 2007; Pitchaon, Sirikarn, \& Pitiporn, 2008; Krishna et al., 2010; Reihani \& Azhar, 2012; Boonyadist et al., 2013; Shrawan et al., 2015). However, a sole method of evaluating antioxidant activities of plant extracts was not sufficient to identify all possible mechanisms characterising an antioxidant. Moreover, antihypertensive activity evaluation of ulam (salad), vegetables and other herbs are yet to be widely conducted. Therefore, the objective of the present work is to evaluate the antioxidant activity of several Malaysian ulam (salad), vegetables and herbs using three different methods and to evaluate the antihypertensive activity.

\section{Materials and Methods}

\subsection{Plants}

Plants were categorized into four groups, namely ulam (salad), local vegetables, legumes vegetables and herbs. The type of plants selected on each category and the specific parts used for this study were presented in Table 1 . The plants selected were based on the types of ulam (salad), vegetables and herbs that were commonly consumed among Malaysians. All fresh samples were purchased from wet market in Bandar Baru Bangi, Selangor.

Table 1. List of selected Malaysian ulam (salad), vegetables and herbs

\begin{tabular}{llll}
\hline Category & English Name & Scientific Name & Part Used \\
\hline Ulam & Stink bean & Parkia speciosa & Seed \\
& Indian pennywort & Centella asiatica & All except root \\
& Water Dropwort & Oenanthe javanica & Shoot \\
& Ulam raja & Cosmos caudatus & Shoot \\
\hline Local Vegetables & Sweet leaf & Sauropus androgynus & Leaf \\
& Fern & Diplazum esculentum & Shoot \\
& Bastard mustard & Gynandropsis gynandra & Leaf \\
& Vegetable hummingbird & Sesbania grandiflora & Leaf \\
\hline Legumes Vegetables & Winged bean & Psophocarpus tetragonolobus & Pod \\
& Drumstick tree & Moringa oleifera & Pod \\
& Okra & Hibiscus esculentus & Pod \\
& Long Bean & Vigna sinensis & Pod \\
\hline \multirow{2}{*}{ Herbs } & Curry tree & Murraya koenigii & Leaf \\
& Kaffir lime & Citrus hystrix & Leaf \\
& Turmeric & Curcuma longa & Leaf \\
& Pygmy smartweed & Polygonum minus & Shoot \\
\hline
\end{tabular}

\subsection{Chemicals}

Chemicals used were acquired from Sigma ${ }^{\circledR}$ [Angiotensin-I Converting Enzyme (ACE), Boric acid, 2,2'-azino-bis(3-ethylbenzothiazoline-6-sulphonic acid) (ABTS), Gallic acid, 2,2-diphenyl-1-picryl hydrazyl (DPPH), ferric chloride hexahydrate $\left(\mathrm{FeCl}_{3} \cdot 6 \mathrm{H}_{2} \mathrm{O}\right)$, ferrous sulfate $\left(\mathrm{FeSO}_{4}\right)$, Hippuryl-L-Histidil-L-Leucine (HHL), potassium persulfate $\left(\mathrm{K}_{2} \mathrm{~S}_{2} \mathrm{O}_{8}\right)$, sodium acetate trihydrate $\left(\mathrm{C}_{2} \mathrm{H}_{3} \mathrm{NaO}_{2} \cdot 3 \mathrm{H}_{2} \mathrm{O}\right)$, sodium carbonate $\left(\mathrm{Na}_{2} \mathrm{CO}_{3}\right)$, sodium chloride $(\mathrm{NaCl})$, sodium tetrahydroxyborate $\left(\mathrm{H}_{4} \mathrm{BNaO}_{4}\right)$, 2,4,6-tri (2-pyridyl)-s-triazine (TPTZ)] and Merck [glacial acetic acid, hydrochloric acid $(\mathrm{HCl})$, ethyl acetate, methanol, Folin-Ciocalteu reagent].

\subsection{Sample Preparation and Extraction}

The edible portion of each samples were separated and washed under running tap water. They were drained and air-dried. The samples were then chopped into small pieces and weighed. Next, the samples were stored at $-80^{\circ} \mathrm{C}$ and freeze dried for 48 hours (Beta 2-8 LDplus, Christ, Germany). Upon freeze-drying, the samples were 
weighed and homogenized using a commercial blender (7011HS, Waring, U.S.A). The ground samples were stored in air-tight container at $-20^{\circ} \mathrm{C}$ prior to extraction. The extract was prepared according to the method by Wong, Leong and Koh (2006) with some modifications. Five gram of ground sample was weighed and added with $250 \mathrm{~mL}$ of distilled water. This was followed by agitation of the mixture at $100 \mathrm{rpm}$ using shaker (Innova 2000/2050, New Brunswick, Germany) for 24 hours at room temperature. The mixture was then filtered using filter paper No. 1 (Whatman, U.K) and lyophilised for 48 hours using freeze-dryer (Beta 2-8 LDplus, Christ, Germany). The dried samples were stored at $-20^{\circ} \mathrm{C}$ for further analysis. The percentage of extract yield was calculated as below:

$$
\% \text { yield }=\frac{\text { Weight of sample extract }}{\text { Initial weight of the sample }} \times 100
$$

\subsection{Determination of Total Phenolic Content (TPC)}

TPC in the aqueous extract of plants was determined according to the Folin Ciocalteu method (Singleton \& Rossi, 1965). For each sample, $1 \mathrm{~mL}$ of aqueous extract $(5 \mathrm{mg} / \mathrm{mL})$ was transferred into test tube. Then $5 \mathrm{~mL}$ of 10 times diluted Folin Ciocalteu reagent were added and allowed to stand for 5 minutes. After 5 minutes, $4 \mathrm{~mL}$ of sodium carbonate was added and the mixture was incubated at room temperature for 2 hours in the dark. The absorbance was measured at $725 \mathrm{~nm}$ using a UV-VIS microplate reader (Epoch, Biotech, U.S.A). The standard curve was prepared using gallic acid at a series of concentrations of 0 to $100 \mathrm{ppm}$. The TPC was expressed as gallic acid equivalent per gram of dry weight ( $\mathrm{mg} \mathrm{GAE} / \mathrm{g}$ ).

\subsection{Antioxidant Activity Assays}

Antioxidant activity assays in the aqueous extract of plants was determined using three method. The first method was performed using DPPH scavenging test as described by Brand-Williams, Cuvelier and Berset (1995) with some modifications. For each sample, $500 \mu \mathrm{L}$ of aqueous extract $(500 \mu \mathrm{g} / \mathrm{mL})$ was mixed with $2.5 \mathrm{~mL}$ of 0.1 $\mathrm{mM}$ DPPH. The mixture was then incubated for 30 minutes in the dark. The control sample was prepared by mixing $500 \mu \mathrm{L}$ of distilled water with $2.5 \mathrm{~mL}$ of $0.1 \mathrm{mM}$ DPPH. After 30 minutes, absorbance was measured at $517 \mathrm{~nm}$ using UV-VIS microplate reader (Epoch, Biotech, U.S.A). Percentage of DPPH scavenging activity was calculated as below:

$$
\mathrm{DPPH} \text { scavenging activity }(\%)=\frac{\mathrm{A}(\text { control })-\mathrm{A}(\text { sample })}{\mathrm{A}(\text { control })} \times 100
$$

where, $\mathrm{A}$ is the absorbance and $\mathrm{A}$ (control) is the absorbance of the reaction containing distilled water and 0.1 $\mathrm{mM}$ DPPH.

The second method used ABTS radical cation as described by Arnao, Cano and Acosta (2001) with some modifications. For each samples, $500 \mu \mathrm{L}$ of aqueous extract $(500 \mu \mathrm{g} / \mathrm{mL})$ were mixed with $2.5 \mathrm{~mL}$ of ABTS solution and incubated for 10 minutes in the dark. After 10 minutes, absorbance was measured at $734 \mathrm{~nm}$ using a UV-VIS microplate reader (Epoch, Biotech, U.S.A). Percentage of inhibition was calculated using the following formula:

$$
\% \text { Inhibition }=\frac{\mathrm{A}(\text { control })-\mathrm{A}(\text { sample })}{\mathrm{A}(\text { control })} \times 100
$$

where, $\mathrm{A}$ is absorbance and $\mathrm{A}$ (control) is the absorbance of the reaction containing distilled water and ABTS solution.

The last antioxidant activity method was the ferric reducing power (FRAP) as described by Benzie and Strain (1996) with some modifications. For each samples, $500 \mu \mathrm{L}$ of aqueous extract $(500 \mu \mathrm{g} / \mathrm{mL})$ were mixed with 2.5 $\mathrm{mL}$ of FRAP reagent and allowed to react in the dark for 30 minutes. After 30 minutes, absorbance was measured at $593 \mathrm{~nm}$ using a UV-VIS microplate reader (Epoch, Biotech, U.S.A). Different concentrations of ferrous sulfate $(0.1-1.0 \mathrm{mM})$ were prepared as standard. FRAP activity was calculated as a proportion of $\mathrm{mM}$ ferrous sulfate obtained from the standard curve of ferrous sulfate. The FRAP activity was expressed in mmol $\mathrm{Fe}^{2+} / \mathrm{g}$.

\subsection{Angiotensin Converting Enzyme (ACE) Inhibitory Activity Assay}

ACE inhibitory activity was determined following the method described by Ngo, Ryu and Kim (2014) with some modifications. A total of $50 \mu \mathrm{L}$ of ACE enzyme $(25 \mathrm{mU} / \mathrm{mL})$ was mixed with $50 \mu \mathrm{L}$ of aqueous extract of plants $(500 \mu \mathrm{g} / \mathrm{mL})$ and incubated at $37^{\circ} \mathrm{C}$ for 10 minutes. Next, $150 \mathrm{~mL}$ Hippuryl-L-Histidyl-L-Leucine (HHL) (8.3 
mM HHL in $50 \mathrm{mM}$ sodium borate buffer containing $0.5 \mathrm{M} \mathrm{NaCl}, \mathrm{pH} 8.3$ ) was added and the mixture was incubated at $37^{\circ} \mathrm{C}$ for 30 minutes. Finally, the reaction was inhibited by adding $250 \mu \mathrm{L}$ of $1 \mathrm{M} \mathrm{HCl}$. The resulting hippuric acid was extracted with addition of $500 \mu \mathrm{L}$ ethyl acetate. After centrifugation $(3000 \mathrm{rpm}, 10$ minutes), $200 \mu \mathrm{L}$ of the upper layer was transferred into the tube and dried at $90^{\circ} \mathrm{C}$ for 10 minutes. The hippuric acid was redissolved in $1 \mathrm{~mL}$ of distilled water and the absorbance was measured at $228 \mathrm{~nm}$ using a UV-VIS microplate reader (Epoch, Biotech, U.S.A). ACE inhibitory activity was calculated according to the following equation:

$$
\text { Inhibitory activity }(\%)==\frac{\mathrm{A}(\text { control })-\mathrm{A}(\text { sample })}{\mathrm{A}(\text { control })-\mathrm{A}(\text { blank })} \times 100
$$

where, A is absorbance and A (control) is the absorbance of the reaction containing distilled water and ACE enzyme $(25 \mathrm{mU} / \mathrm{mL})$.

\subsection{Statistical Analysis}

The data was analysed using Statistical Packages for Social Science (SPSS) version 21.0. Analysis of variance (ANOVA) followed by Duncan's multiple range test was used to test the significant difference among the samples. Pearson correlation was used to test the association between the TPC and the antioxidant activity and ACE inhibitory activity. The results were reported as mean \pm standard deviation.

\section{Results}

\subsection{Extraction Yield}

The yield of plant aqueous extract was in the range of 5.03 to $12.42 \%$, as presented in the Table 2. Moringa oleifera showed the highest extraction yield (12.42\%) while P. minus was the lowest (5.03\%). Extraction yield of M. oleifera was significantly higher $(\mathrm{p}<0.05)$ compared to the other plants.

Table 2. Extraction yield and total phenolic content of selected Malaysian ulam (salad), vegetables and herbs

\begin{tabular}{lcc}
\hline Plants & Yield of extracts (\%) & Total phenolic content (mg GAE/g) \\
\hline Ulam & & \\
\hline Parkia speciosa & $5.14 \pm 0.01^{\mathrm{def}}$ & $3.77 \pm 0.10^{\mathrm{c}}$ \\
Centella asiatica & $5.10 \pm 0.01^{\mathrm{bcd}}$ & $6.42 \pm 0.15^{\mathrm{h}}$ \\
Oenanthe javanica & $5.08 \pm 0.02^{\mathrm{ab}}$ & $4.84 \pm 0.00^{\mathrm{e}}$ \\
Cosmos caudatus & $5.09 \pm 0.01^{\mathrm{bcd}}$ & $22.54 \pm 0.29^{\mathrm{m}}$ \\
\hline Local Vegetables & & \\
\hline Sauropus androgynus & $5.11 \pm 0.01^{\mathrm{bcde}}$ & $13.46 \pm 0.23^{\mathrm{j}}$ \\
Diplazum esculentum & $5.16 \pm 0.03^{\mathrm{efg}}$ & $5.49 \pm 0.12^{\mathrm{f}}$ \\
Gynandropsis gynandra & $5.08 \pm 0.07^{\mathrm{ab}}$ & $12.36 \pm 0.17^{\mathrm{i}}$ \\
Sesbania grandiflora & $5.13 \pm 0.02^{\mathrm{cdef}}$ & $13.86 \pm 0.06^{\mathrm{k}}$ \\
\hline Legumes Vegetables & & \\
\hline Psophocarpus tetragonolobus & $5.18 \pm 0.01^{\mathrm{fg}}$ & $6.04 \pm 0.03^{\mathrm{g}}$ \\
Moringa oleifera & $12.42 \pm 0.03^{\mathrm{i}}$ & $2.46 \pm 0.03^{\mathrm{a}}$ \\
Hibiscus esculentus & $5.20 \pm 0.01^{\mathrm{g}}$ & $3.17 \pm 0.09^{\mathrm{b}}$ \\
Vigna sinensis & $5.17 \pm 0.02^{\mathrm{fg}}$ & $4.20 \pm 0.12^{\mathrm{d}}$ \\
\hline Herbs & & \\
\hline Murraya koenigii & $5.13 \pm 0.01^{\mathrm{cdef}}$ & $16.09 \pm 0.06^{\mathrm{n}}$ \\
Citrus hystrix & $6.17 \pm 0.01^{\mathrm{h}}$ & $12.58 \pm 0.23^{\mathrm{h}}$ \\
Curcuma longa & $5.09 \pm 0.01^{\mathrm{bc}}$ & \\
Polygonum minus & $5.03 \pm 0.06^{\mathrm{a}}$ & \\
\hline
\end{tabular}

Results are expressed in mean and standard deviation $(\mathrm{n}=3)$

Values with the same lowercase within each column are not significantly different ( $p>0.05)$

\subsection{TPC Analysis}

TPC of plant aqueous extract are also presented in Table 2; and it ranged from $2.46 \mathrm{mg}$ to $48.23 \mathrm{mg} \mathrm{GAE} / \mathrm{g}$. $P$. minus showed the highest TPC (48.23 mg GAE/g extract) whereas the lowest TPC was observed in M. oleifera (2.46 mg GAE/g extract). TPC value for P. minus was significantly higher $(\mathrm{p}<0.05)$ compared to the other plants. 
TPC analysis of all plant aqueous extract are ranked from highest to lowest in the order of $P$. minus $>M$. koenigii $>$ C. caudatus $>$ C. hystrix $>$ S. grandiflora $>$ S. androgynus $>C$. longa $>$ G. gynandra $>C$. asiatica $>P$. tetragonolobus $>$ D. esculentum $>$ O. javanica $>V$. sinensis $>$ P. speciosa $>H$. esculentus $>$ M. oleifera.

\subsection{Antioxidant Activity Assays}

Table 3 shows antioxidant activity assays (DPPH, ABTS and FRAP) of the aqueous extract of analyzed plants. $P$. minus showed significantly the highest free radical scavenging activity of $79.09 \pm 0.10 \%$ compared to other plants ( $\mathrm{p}<0.05$ ). The percentage of DPPH free radical scavenging activity for all other studied plants could be explained in decreasing order of $S$. grandiflora $>$. gynandra $>M$. koenigii $>C$. caudatus $>S$. androgynus $>O$. javanica $>$ C. hystrix $>$ P. speciosa $>C$. asiatica $>$ C. longa $>$ P. tetragonolobus $>$ M. oleifera $>$ D. esculentum $>H$. esculentus $>V$. sinensis. While $S$. androgynus extract showed the highest ABTS radical cation scavenging activity $(95.10 \pm 0.26 \%)$ compared to other plants studied. The ABTS radical cation scavenging activity of the plant aqueous extract are in the order of $S$. androgynus $>$ P. minus $>C$. longa $>$ M. koenigii $>$ C. caudatus $>$ G. gynandra $>$ C. hystrix $>$ D. esculentum $>$ S. grandiflora $>$ P. speciosa $>$ C. asiatica $>$ P. tetragonolobus $>V$. sinensis $>H$. esculentus $>$ O. javanica $>$ M. oleifera. For FRAP assay, P. minus showed significantly the highest ferric reducing activity of $63.61 \pm 0.73 \mathrm{mM} / \mathrm{g}$ as compared to other plants $(\mathrm{p}<0.05)$. The order of ferric reducing activity of the aqueous extract were: P. minus $>M$. koenigii $>C$. caudatus $>$. gynandra $>C$. longa $>C$. hystrix $>S$. androgynus $>$ D. esculentum $>C$. asiatica $>$ O. javanica $>$ S. grandiflora $>$ P. tetragonolobus $>$ M. oleifera $>V$. sinensis $>$ H. esculentus $>$ P. speciosa.

Table 3. Antioxidant activities (DPPH, ABTS and FRAP) of selected Malaysian ulam (salad), vegetables and herbs

\begin{tabular}{llll}
\hline Plants & DPPH (\%) & ABTS (\%) & FRAP $\left(\mathbf{m m o l ~ F e}^{2+} / \mathbf{g}\right)$ \\
\hline Ulam & & & \\
\hline Parkia speciosa & $56.05 \pm 1.00^{\mathrm{f}}$ & $68.10 \pm 1.00 \mathrm{~d}^{\mathrm{e}}$ & $1.62 \pm 0.03^{\mathrm{a}}$ \\
Centella asiatica & $47.98 \pm 2.65^{\mathrm{e}}$ & $65.42 \pm 4.41^{\mathrm{d}}$ & $8.77 \pm 0.21^{\mathrm{d}}$ \\
Oenanthe javanica & $63.44 \pm 0.58^{\mathrm{g}}$ & $40.37 \pm 1.46^{\mathrm{a}}$ & $6.68 \pm 0.20^{\mathrm{c}}$ \\
Cosmos caudatus & $64.38 \pm 1.15^{\mathrm{g}}$ & $91.71 \pm 0.22^{\mathrm{gh}}$ & $28.46 \pm 2.09^{\mathrm{i}}$ \\
\hline Local Vegetables & & & \\
\hline Sauropus androgynus & $64.29 \pm 0.00^{\mathrm{g}}$ & $95.23 \pm 0.26^{\mathrm{h}}$ & $13.64 \pm 6.01^{\mathrm{f}}$ \\
Diplazum esculentum & $29.76 \pm 0.00^{\mathrm{c}}$ & $84.75 \pm 0.26^{\mathrm{f}}$ & $12.30 \pm 0.77^{\mathrm{e}}$ \\
Gynandropsis gynandra & $69.76 \pm 1.73^{\mathrm{h}}$ & $91.59 \pm 1.73^{\mathrm{gh}}$ & $15.62 \pm 0.22^{\mathrm{h}}$ \\
Sesbania grandiflora & $72.88 \pm 2.33^{\mathrm{h}}$ & $69.67 \pm 0.87^{\mathrm{e}}$ & $6.01 \pm 0.45^{\mathrm{c}}$ \\
\hline Legumes Vegetables & & & \\
\hline Psophocarpus tetragonolobus & $46.89 \pm 3.06^{\mathrm{e}}$ & $59.79 \pm 3.15^{\mathrm{c}}$ & $4.40 \pm 0.08^{\mathrm{b}}$ \\
Moringa oleifera & $37.19 \pm 2.00^{\mathrm{d}}$ & $37.38 \pm 5.94^{\mathrm{a}}$ & $3.70 \pm 0.02^{\mathrm{b}}$ \\
Hibiscus esculentus & $21.76 \pm 7.00^{\mathrm{b}}$ & $51.01 \pm 0.50^{\mathrm{b}}$ & $3.16 \pm 0.05^{\mathrm{b}}$ \\
Vigna sinensis & $15.87 \pm 0.00^{\mathrm{a}}$ & $58.00 \pm 2.05^{\mathrm{c}}$ & $3.68 \pm 0.06^{\mathrm{b}}$ \\
\hline Herbs & & \\
\hline Murraya koenigii & $64.73 \pm 0.10^{\mathrm{g}}$ & $92.70 \pm 0.80^{\mathrm{gh}}$ & $32.90 \pm 1.29^{\mathrm{j}}$ \\
Citrus hystrix & $58.48 \pm 0.10^{\mathrm{f}}$ & $90.32 \pm 0.20^{\mathrm{g}}$ & $14.31 \pm 0.41^{\mathrm{fg}}$ \\
Curcuma longa & $47.82 \pm 0.96^{\mathrm{e}}$ & $92.78 \pm 0.26^{\mathrm{gh}}$ & $15.27 \pm 0.45^{\mathrm{gh}}$ \\
Polygonum minus & $79.09 \pm 0.00^{\mathrm{i}}$ & $93.04 \pm 0.01^{\mathrm{gh}}$ & $63.61 \pm 0.98^{\mathrm{k}}$ \\
\hline
\end{tabular}

Results are expressed in mean and standard deviation $(\mathrm{n}=3)$

Values with the same lowercase within each column are not significantly different ( $p>0.05)$

\subsection{ACE Inhibitory Activity Assay}

The ACE inhibitory activity of plant aqueous extract was presented in Table 4 . The results showed that only aqueous extract of C. longa, P. speciosa, G. gynandra, C. asiatica, C. caudatus, P. minus, C. hystrix and M. koenigii showed ACE inhibitory activity which were $33.89 \pm 0.96,33.89 \pm 0.96,35.55 \pm 3.85,73.63 \pm 12.00,88.49$ $\pm 0.85 \%, 89.13 \pm 5.42 \%, 90.20 \pm 4.15 \%$ and $91.20 \pm 4.15 \%$, respectively. The inhibitory activity was not detected in all other extracts. 
Table 4. ACE inhibitory activities of selected Malaysian ulam (salad), vegetables and herbs

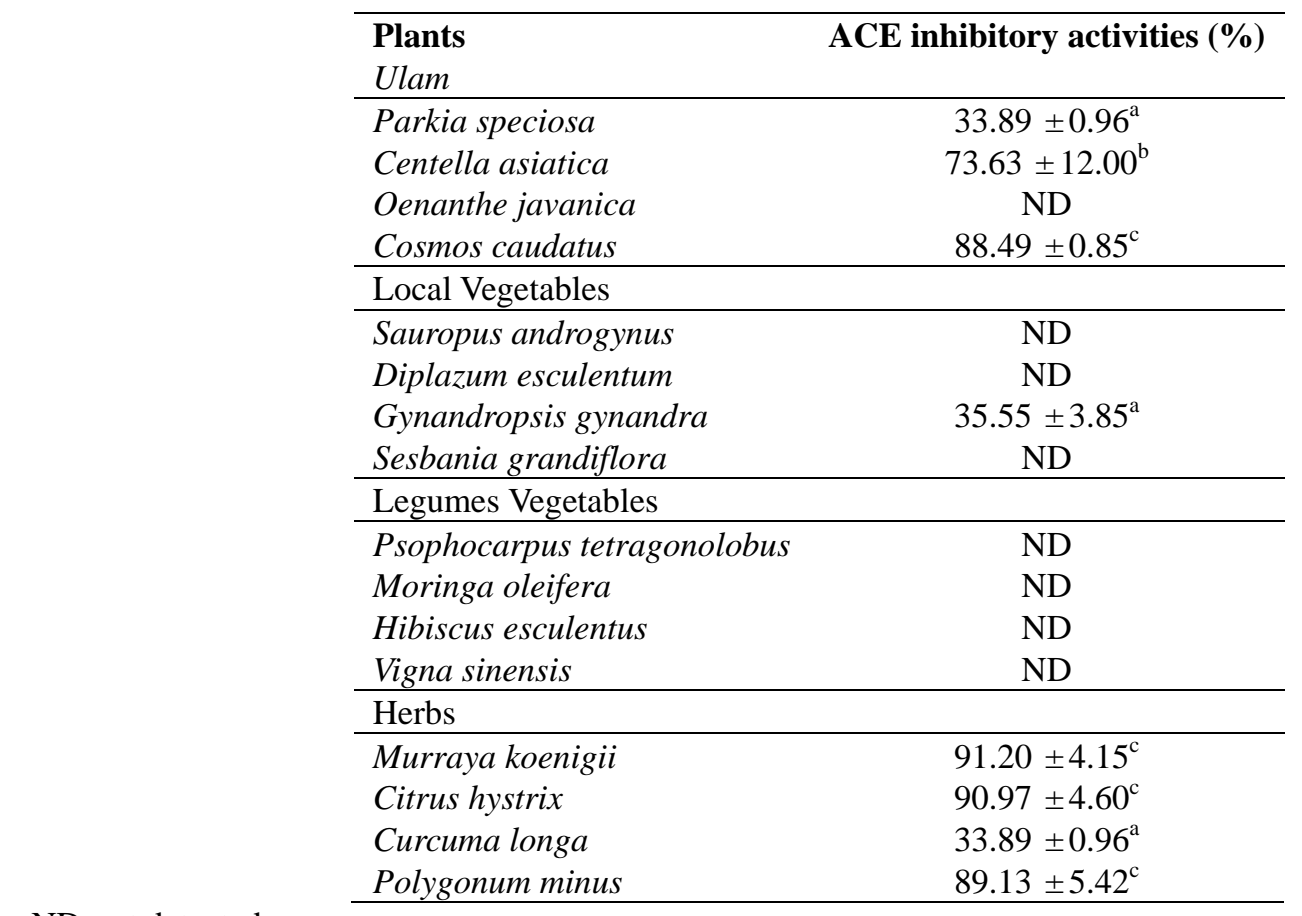

ND-not detected

Results are expressed in mean and standard deviation $(n=3)$

Values with the same lowercase within column are not significantly different $(p>0.05)$

\subsection{Correlation}

The correlation between total phenolic content with antioxidant activity and ACE inhibitory activity was shown in Table 5. The results revealed that there was a strong correlation between TPC and FRAP $(r=0.956)$ followed by the TPC and ABTS $(r=0.635)$, and TPC with DPPH $(r=0.630)$. From Table 5, there was a positive correlation between TPC and ACE $(r=0.645)$. The antioxidant activity using DPPH, ABTS and FRAP assay in this study also showed a strong correlation. The highest correlation was observed between ABTS and FRAP assay $(r=0.651)$, while the lowest correlation was detected between DPPH and ABTS assay $(r=0.480)$.

Table 5. Correlation Analysis

\begin{tabular}{lc}
\hline Parameter & Correlation Value $(\mathbf{r})$ \\
\cline { 2 - 2 } TPC/DPPH & $0.630^{*}$ \\
TPC/ABTS & $0.635^{*}$ \\
TPC/FRAP & $0.956^{*}$ \\
TPC/ACE & $0.645^{*}$ \\
DPPH/ABTS & $0.480^{*}$ \\
DPPH/FRAP & $0.551^{*}$ \\
ABTS/FRAP & $0.615^{*}$ \\
\hline
\end{tabular}

*significant correlation $\mathrm{p}<0.01$

\section{Discussions}

The plant's active compounds usually occur in low concentration, therefore, an extraction technique is needed in order to obtain the required extract with high yield and minimal changes to the functional properties. (Quispe Candori, Foglio, Rosa, \& Meireles, 2008). Based on our findings, percentage of extraction yield was higher from the leguminous parts compared to the leafy parts. A previous study by Pitchaon et al. (2008) also showed that 
better extraction yield could be achieved from nuts and fruits (1.3-4.5\%) than leaves and flowers (0.7-2.5\%). Besides, a study of Lee et al. (2011) reported that the extraction yield of P. tetragonolobus $(8.53 \%)$ was higher compared with $S$. androgynus (5.20\%). Sample particle size, extraction temperature and extraction ratio of solvent to samples are some of the factors that influence percentage of extraction (Herodez, Hadolin, Skerget, \& Knez, 2003).

Antioxidants are capable of either delaying or inhibiting the oxidation process that occurs due to presence of free radicals (Pisoschi \& Negulescu, 2011). Free radicals promote lipid, DNA, protein and carbohydrate damage that cause various diseases such as cancer, atherosclerosis and rheumatoid arthritis (Aruoma, 1994). Antioxidant acts with free radicals by donating one electrons to free radical atom that neutralizes the effects of oxidative damage (Valko et al., 2007). Epidemiological studies have shown that intake of natural antioxidant like phenolics from vegetables and fruits were associated with lower risk of cancer (Temple, 2000; Wolfe \& Liu, 2003). The aqueous extract of all analyzed 16 plants contained varying amount of TPC. Naczk and Shahidi (2006) reported that extraction method using more polar solvent, longer extraction time and larger sample to solvent ratio will result in higher amount of phenolic compounds. In addition, cultivars and climate are also among the other factors that influence the phenolic structure and bioactive components in plants (Bolling, Dolnikowski, Blumberg, \& Chen, 2010). P. minus contained the highest TPC among the studied samples. Huda-Faujan et al. (2007) also reported the highest contents of the TPC in P. minus (44.35 mg TAE/100g). P. minus is a herb that is often used as a seasoning for preparation of fish, noodles and other Malay cuisine (Rukayah, 2000). P. minus was reported to have several medicinal properties such as antimicrobial activity (Uyub, Nwachukwu, Azlan, \& Fariza, 2010), cytotoxic activity towards human cervical carcinoma (Mackeen et al., 1997), antioxidant activity (Huda-Faujan et al., 2007) and anticancer activity (Abdullah, Mavaddat, \& Mohd Ali, 2013).

In the present study, determination of antioxidant capacity was done using DPPH, ABTS and FRAP. According to Frankel and Meyer (2000), just one assay method cannot identify all possible mechanisms characterising an antioxidant activity. ABTS method is based on the ability of antioxidant molecules to inhibit the radical cation ABTS that change the color of blue-green complex (Antolovich et al., 2000; Wootton-Beard, Aislin, \& Lisa, 2011). On the other hand, DPPH assay relies on DPPH itself as the stable free radical to determine antioxidant activity in natural compounds. The assay will be determined based on the colour change of purplish DPPH into a yellowish compound of $\alpha, \alpha$-diphenyl- $\beta$-picrylhydrazine (Pisoschi \& Negulescu, 2011). FRAP is a method based on reaction of sample extract that results in colour change from colourless Fe (III) to the blue colour complex of Fe (II) (Antolovich et al., 2000; Wootton-Beard et al., 2011). P. minus showed the highest DPPH free radical scavenging activity and ferric reducing activity. Maizura, Aminah and Wan Aida (2011) also reported the highest DPPH free radical scavenging activity of $P$. minus extract $(82.6 \pm 0.7 \%)$ compared to Zingiber officinale $(79.0 \pm 0.6 \%)$ and $C$. longa $(64.6 \pm 2.4 \%)$. On the other hand, $S$. androgynus extract resulted in the highest ABTS radical cation scavenging activity. Similarly, $S$. androgynus extract was also reported to potray the highest ABTS inhibitory activity in another separate study conducted by Andarwulan, Ratna, Diny, Bradley and Hanny (2010). ABTS method showed higher values due to it ABTS radical cation's that is reactive towards most antioxidants and it is soluble in aqueous solvent (Martysiak-Zurowska \& Wenta, 2012). However, O. javanica and S. grandiflora showed higher value using DPPH method maybe due to some compounds react very rapidly with DPPH (Martysiak-Zurowska \& Wenta, 2012). Generally, the extracts with high amounts of phenolic content showed high antioxidant activity (Bolling et al., 2010). The reduction potential of Fe (III) is contributed by the phenolic components in the extracts which donated the hydrogen and reduced the Fe (III)-TPTZ to Fe (II)-TPTZ complex (Shimada, Fujikawa, Yahara, \& Nakamura, 1992).

ACE inhibitory activity was conducted via ethyl acetate extraction and spectrophotometric assay of hippuric acid (Cushman \& Cheung, 1971). ACE inhibitory activity was only detected in aqueous extract of C. longa, P. speciosa, G. gynandra, C. asiatica, C. caudatus, P. minus, C. longa and M. koenigii. TPC analysis indicated high phenolic content in the aqueous extract of these plants. A study conducted by Dong, Xu, Liang, Head and Bennett (2011) showed that antioxidants such as polyphenols extracted from the sample can act as an ACE inhibitor. C. caudatus is the most preferred ulam by Malaysian community while P. minus, C. hystrix and M. koenigii are a herb that is often used in dishes such as laksa, tom yam and curry stew. They also believe that these herbs have medicinal properties such as anticancer and antihypertensive (Rukayah, 2000; Wan Hassan \& Mustaffa, 2010; Jamilah, Abdul Kadir Gedi, Suhaila, \& Md. Zaidul, 2011).

Correlation analysis was conducted to examine the relationship between two variables. Previous studies reported that phenolics compounds in vegetables and herbs significantly contributed to their antioxidant properties (Wong et al., 2006; Huda-Faujan et al. 2007; Maizura et al., 2011). Strong correlation between TPC and FRAP $(r=0.956)$, TPC and ABTS $(r=0.635)$ and TPC with DPPH $(r=0.630)$ was observed among all the 16 plants. It showed that, 
the higher total phenolics content of plants extracts resulted in higher antioxidant activity. A previous study by Wan-Ibrahim, Sidik and Kuppusamy (2012) also indicated a strong correlation between TPC and FRAP $(r=0.887)$ and TPC with DPPH ( $r=0.984)$ among the 20 plants analyzed. Rice-Evans, Miller and Paganga (1997) stated that the phenolic compound acts as a reducing agent, hydrogen donors and oxygen trappers which plays an important role in determining the antioxidant potential. Whereas, high DPPH free radical scavenging activity was contributed by low molecular content. Positive correlation was also observed between TPC and ACE $(r=0.645)$. Nadin et al. (2013) reported that ACE inhibition mechanism involves the interaction of three phenolic groups of gallic acid, phenolic acids and flavonoids and other flavonoids with ACE active group. Positive correlations between DPPH, ABTS and FRAP assays were observed. The highest correlation was between ABTS and FRAP (r $=0.615)$ and the lowest correlation was between DPPH and ABTS $(r=0.481)$. The high correlation between ABTS and FRAP implies that ABTS radical cation react rapidly with antioxidants (Martysiak-Zurowska \& Wenta, 2012) and the FRAP technique showed high reproducibility (Thaipong et al., 2006). While the low correlation between DPPH and ABTS implies that the reaction of DPPH with most antioxidants is slower compared with ABTS radical cation as reported by Martysiak-Zurowska and Wenta (2012).

\section{Conclusions}

In conclusion, $P$. minus showed the highest total phenolic content $(48.23 \mathrm{mg} \mathrm{GAE} / \mathrm{g})$ and antioxidant activity (DPPH: $79.09 \pm 0.1 \%$, FRAP: $63.61 \pm 0.73 \mathrm{mmol} \mathrm{Fe} / \mathrm{g}$ ) among all the aqueous extract. Whereas, the highest ACE inhibitory activity was detected in $M$. koenigii extract $(91.20 \pm 4.15 \%)$. The findings from our study attracts interests on one of the selected Malaysian plants, P. minus as a promising source of antioxidants and antihypertensive.

\section{Acknowledgments}

The authors thank the Director General of Health Malaysia and the Director of Institute for Medical research (IMR) for permission to publish this article. We also thank all the staffs from Faculty Science and Technology, Universiti Kebangsaan Malaysia which have been involved throughout the study for all support and assistance.

\section{References}

Abdullah, M. Z., Mavaddat, M. H., \& Mohd Ali, J. (2013). Antioxidant and anticancer activities of Polygonum minus, Alpinia galanga and Etlingera elatior. The Open Conference Proceedings Journal, 4, 203. https://doi.org/10.2174/2210289201304010203

Andarwulan, N., Ratna, B., Diny, A. S., Bradley, B., \& Hanny, W. (2010). Flavonoid content and antioxidant activity of vegetables from Indonesia. Food Chemistry, 121, 1231-1235. https://doi.org/10.1016/j.foodchem.2010.01.033

Antolovich, M., Prenzler, P., Kevin, R., \& Danielle, R. (2000). Sample preparation in the determination of phenolic compounds in fruits. Analyst, 125, 989-1009. https://doi.org/10.1039/b000080i

Arnao, M. B., Cano, A., \& Acosta, M. (2001). The hydrophilic and lipophilic contribution to total antioxidant activity. Food Chemistry, 73, 239-244. https://doi.org/10.1016/S0308-8146(00)00324-1

Aruoma, O. I. (1994). Nutrition and health aspects of free radicals and antioxidants. Food and Chemical Toxicology, 62, 671-683. https://doi.org/10.1016/0278-6915(94)90011-6

Benzie, I. F. F., \& Strain, J. J. (1996). The ferric reducing ability of plasma (FRAP) as a measure of "antioxidant power": the FRAP assay. Analytical Biochemistry, 239, 70-76. https://doi.org/10.1006/abio.1996.0292

Bolling, B. W., Dolnikowski, G., Blumberg, J. B., \& Chen, C. Y. (2010). Polyphenol content and antioxidant activity of California almonds depend on cultivar and harvest year. Food Chemistry, 122(3), 819-825. https://doi.org/10.1016/j.foodchem.2010.03.068

Boonyadist, V., Pongtip, S., Supachoke, M., Suchitra, T., Yuvadee, W., \& Wandee, G. (2013). Maximizing total phenolics, total flavonoids contents and antioxidant activity of Moringa oleifera leaf extract by the appropriate extraction method. Industrial Crops and Products, 44, 566-571. https://doi.org/10.1016/j.indcrop.2012.09.021

Brand-Williams, W., Cuvelier, M. E., \& Berset, C. (1995). Use of free radical method to evaluate antioxidant activity. LWT-Food Science and Technology, 28, 25-30. https://doi.org/10.1016/S0023-6438(95)80008-5

Campanella, L., Martini, E., Rita, E., \& Tomassetti, M. (2006). Antioxidant capacity of dry vegetal extracts checked by voltammetric method. Journal of Food Agriculture and Environment, 4, 135-144.

Cushman, D. W., \& Cheung, H. S. (1971). Spectrophotometric assay and properties of the angiotensin 
I-converting enzyme of rabbit lung. Biochemical Pharmacology, 20, 1637-1648. https://doi.org/10.1016/0006-2952(71)90292-9

Dong, J., Xu, X., Liang, Y., Head, R., \& Bennett L. (2011). Inhibition of angiotensin converting enzyme (ACE) activity by polyphenols from tea (Camellia sinensis) and links to processing method. Food \& Function, 2, 310-319. https://doi.org/10.1039/C1FO10023H

Faridah, A., Nordin, H. L., Israf, D. A., Khozirah, S., \& Umi Kalsom, Y. (2006). Antioxidant and nitric oxide inhibition activities of selected Malay traditional vegetables. Food Chemistry, 95, 566-573. https://doi.org/10.1016/j.foodchem.2005.01.034

Halvorsen, B. L., Carlsen, M. H., Phillips, K. M., Bohn, S. K., \& Holte, K. (2006). Content of redox-active compounds (antioxidants) in foods consumed in the United States. The American Journal of Clinical Nutrition, 84, 95-135.

Herodez, S. S., Hadolin, M., Skerget, M., \& Knez, Z. (2003). Solvent extraction study of antioxidants from balm (Melissa officinalis L.) leaves. Food Chemistry, 80(2), 275-282. https://doi.org/10.1016/S0308-8146(02)00382-5

Huda-Faujan, N., Noriham, A., Norrakiah, A. S., \& Babji, A. S. (2007). Antioxidative activities of water extracts of some Malaysian herbs. ASEAN Food Journal, 14(1), 61-68.

Jamilah, B., Abdul Kadir Gedi, M., Suhaila, M., \& Md. Zaidul, I.S. (2011). Phenolics in Citrus hystrix leaves obtained using supercritical carbon dioxide extraction. International Food Research Journal, 18(3), 941-948.

Krishna, P. L., Vino, T., Cheriyan, B., Vineshkumar, T., Puliappadamba, Smitha, V., ... Ruby, J. A. (2010). A novel protein fraction from Sesbania grandiflora shows potential anticancer and chemopreventive efficacy, in vitro and in vivo. Journal of Cellular and Molecular Medicine, 14(3), 636-646. https://doi.org/10.1111/j.1582-4934.2008.00648.x

Lee, K. H., Padzil, A. M., Syahida, A., Abdullah, N., Zuhainis, S. W., Maziah, M, ... Lajis, N. H. (2011). Evaluation of anti inflammatory, antioxidant and antinociceptive activities of six Malaysian medicinal plants. Journal of Medical Plants Research, 5(23), 5555-5563.

Lindsay, D. G., \& Astley, S. B. (2002). European research on the functional effects of dietary antioxidants-EUROFEDA. Molecular Aspects of Medicine, 23, 1-38. https://doi.org/10.1016/S0098-2997(02)00019-5

Mackeen, M. M., Ali, A. M., El-Sharkawy, S. H., Manap, M. Y., Salleh, K. M., Lajis, N. H., \& Kazaku, K. (1997). Antimicrobial and cytotoxic properties of some Malaysian traditional vegetables (Ulam). Pharmaceutical Biology, 35, 174-178. https://doi.org/10.1076/phbi.35.3.174.13294

Maizura, R., Aminah, A., \& Wan Aida, W. M. (2011). Total phenolic content and antioxidant activity of kesum (Polygonum minus), ginger (Zingiber officinale) and turmeric (Curcuma longa) extract. International Food Research Journal, 18, 526-531.

Martysiak-Zurowska, D., \& Wenta, W. (2012). A comparison of ABTS and DPPH methods for assessing the total antioxidant capacity of human milk. Acta Scientiarium Polonorum Technologia Alimentaria, 11(1), 83-89.

Mohd Faez, B., Barakatun-Nisak, M. Y., Amin, I., \& Azizah, A. H. (2014). Effectiveness of traditional Malaysian vegetables (ulam) in modulating blood glucose levels. Asia Pacific Journal of Clinical Nutrition, 23(3), 369-376. https://doi.org/10.6133/apjcn.2014.23.3.01

Naczk, M., \& Shahidi, F. (2006). Phenolics in cereals, fruits and vegetables: occurrence, extraction and analysis. Journal of Pharmaceutical and Biomedical Analysis, 41, 1523-1542. https://doi.org/10.1016/j.jpba.2006.04.002

Nadin, A. S., John, V. C., Gerard, B. G., Dorien, S., Karin, S., Moises, J. Z., ... Guy, S. (2013). Angiotensin-converting enzyme inhibitory effects by plant phenolic compounds: a study of structure activity relationships. Journal of Agricultural and Food Chemistry 61(48), 11832-11839. https://doi.org/10.1021/jf404641v

Ngo, D-H., Ryu, B., \& Kim, S-K. (2014). Active peptides from skate (Okamejei kenojei) skin gelatin diminish angiotensin-I converting enzyme activity and intracellular free radical-mediated oxidation. Food Chemistry, 143, 246-255. https://doi.org/10.1016/j.foodchem.2013.07.067

Nurul Izzah, A., Aminah, A., Md Pauzi, A., Lee, Y. H., Wan Rozita, W. M., \& Siti Fatimah, D. (2012). Patterns of 
fruits and vegetable consumption among adults of different ethnics in Selangor, Malaysia. International Food Research Journal 19(3), 1095-1107.

Pisoschi, A. M., \& Negulescu, G. P. (2011). Methods for total antioxidant activity determination: a review. Biochemistry \& Analytical Biochemistry, 1, 106-116. http://dx.doi.org/10.4172/2161-1009.1000106

Pitchaon, M., Sirikarn, P., \& Pitiporn, R. (2008). Relationship between antioxidant properties and chemical composition of some Thai plants. Journal of Food Composition and Analysis, 21, 229-240. https://doi.org/10.1016/j.jfca.2007.11.005

Quispe Candori, S., Foglio, M. A., Rosa, P. T. V., \& Meireles, M. A. A. (2008). Obtaining b-caryophyllene from Cordia verbenacea de Candolle by supercritical fluid extraction. The Journal of Supercritical Fluids, 46, 27-32. https://doi.org/10.1016/j.supflu.2008.02.015

Reihani, S. F. S., \& Azhar, M. E. (2012). Antioxidant activity and total phenolic content in aqueous extracts of selected traditional Malaysia salad (ulam). International Food Research Journal, 19(4), 1439-1444.

Rice-Evans, C. A., Miller, N. J., \& Paganga. (1997). Antioxidant properties of phenolic compound. Trends in Plant Science, 4, 304-309. https://doi.org/10.1016/S1360-1385(97)01018-2

Rukayah, A. (2000). Ulam dan sayuran tempatan Semenanjung Malaysia. Kuala Lumpur, KL: Dewan Bahasa dan Pustaka.

Shimada, K., Fujikawa, K., Yahara, K., \& Nakamura, T. (1992). Antioxidative properties of xanthan on the autoxidation of soyabean oil in cyclodextrin emulsion. Journal of Agricultural and Food Chemistry, 40, 945-948. https://doi.org/10.1021/jf00018a005

Shrawan, S., Swain, S., Singh, K. M., Salim, Dipak, N., \& Dam, R. S. (2015). Changes in phytochemicals, anti-nutrients and antioxidant activity in leafy vegetables by microwave boiling with normal and $5 \% \mathrm{NaCl}$ solution. Food Chemistry, 176, 244-253. https://doi.org/10.1016/j.foodchem.2014.12.068

Singleton, V. L., \& Rossi, J. A. (1965). Colorimetry of total phenolics with phosphomolybdic-phosphotungstic acid reagents. American Journal of Enology and Viticulture, 16, 144-158.

Sivanesan, D., \& Hazeena, B. V. (2007). Prevention role of Gynandropsis gynandra L., against aflatoxin B1 induced lipid peroxidation and antioxidant defense mechanism in rat. Indian Journal of Experimental Biology, 45, 299-303.

Temple, N. J. (2000). Antioxidants and disease: more questions than answers. Nutrition Research, 20, 449-459. https://doi.org/10.1016/S0271-5317(00)00138-X

Thaipong, K., Boonprakob, U., Crosby, K., Cisneros-Zevallos, L., \& Byrne, D. H. (2006). Comparison of ABTS, DPPH, FRAP and ORAC assays for estimating antioxidant activity from guava fruit extracts. Journal of Food Composition and Analysis, 19, 669-675. https://doi.org/10.1016/j.jfca.2006.01.003

Uyub, A. M., Nwachukwu, I. N., Azlan, A. A., \& Fariza, S. S. (2010). In-vitro antibacterial activity and cytotoxicity of selected medicinal plant extracts from Penang Island Malaysia on metronidazole-resistant-helicobacter pylori and some pathogenic bacteria. Ethnobotany Research and Applications, 8, 95-106. http://hdl.handle.net/10125/21002

Valko, M., Dieter, L., Jan, M., Mark, T. D., Cronin, M. M., \& Joshua, T. (2007). Free radicals and antioxidants in normal physiological functions and human disease. The International Journal of Biochemistry \& Cell Biology, 39, 44-84. https://doi.org/10.1016/j.biocel.2006.07.001

Wan Hassan, W. E., \& Mustaffa, M. (2010). Ulam salad herbs of Malaysia. Kuala Lumpur: Percetakan Jiwabaru Sdn. Bhd.

Wan-Ibrahim, W. I., Sidik, K., \& Kuppusamy, U. R. (2012). A high antioxidant level in edible plants is associated with genotoxic properties. Food Chemistry 122, 1139-1144. https://doi.org/10.1016/j.foodchem.2010.03.101

Wolfe, K. W. X., \& Liu, R. H. (2003). Antioxidant activity of apple peels. Journal of Agricultural and Food Chemistry, 51(3), 609-614. https://doi.org/10.1021/jf020782a

Wong, S. P., Leong, L. P., \& Koh, J. H. W. (2006). Antioxidant activities of aqueous extracts of selected plants. Food Chemistry 99, 775-783. https://doi.org/10.1016/j.foodchem.2005.07.058

Wootton-Beard, P. C., Aislin, M., \& Lisa, R. (2011). Stability of the total antioxidant capacity and total polyphenol content of 23 commercially available vegetable juices before and after in vitro digestion 
measured by FRAP, DPPH, ABTS and Folin-Ciocalteu methods. Food Research International, 44, $217-224$. https://doi.org/10.1016/j.foodres.2010.10.033

World Health Organization. (2014). Noncommunicable Diseases Country Profiles. WHO Press, Geneva, Switzerland. Retrieved from http://www.who.int/nmh/publications/ncd-profiles-2014/en.

Zheng, W., \& Wang, S. (2001). Antioxidant activity and phenolic composition in selected herbs. Journal of Agricultural and Food Chemistry 49, 5165-5170. https://doi.org/10.1021/jf010697n

\section{Copyrights}

Copyright for this article is retained by the author(s), with first publication rights granted to the journal.

This is an open-access article distributed under the terms and conditions of the Creative Commons Attribution license (http://creativecommons.org/licenses/by/4.0/). 